\title{
Socio-Demographic Factors Affecting the Prevalence of Enteric Fever: A Study in a Tertiary Care Hospital, Dhaka, Bangladesh
}

Md. Mizanur Rahman ${ }^{*}$, ASM Nawshad Uddin Ahmed ${ }^{2}$, Md. Jafar Iqbal ${ }^{3}$, Mohammad Abdullah Al Mamun ${ }^{4}$, Nazia Hossain $^{5}, \mathrm{Md}$. Atiqul Islam ${ }^{6}$

\footnotetext{
${ }^{1}$ Associate Professor and Head, Department of Paediatric Infectious Diseases and Community Paediatrics, Bangladesh Institute of Child Health (BICH), Dhaka Shishu (Children) Hospital, Dhaka, Bangladesh

${ }^{2}$ Professor \& Head, Department of Paediatric Endocrinology, Bangladesh Institute of Child Health (BICH), Dhaka Shishu (Children) Hospital, Dhaka, Bangladesh

${ }^{3}$ Resident Medical Officer, Department of Paediatric Infectious Diseases and Community Paediatrics, Bangladesh Institute of Child Health (BICH), Dhaka Shishu (Children) Hospital, Dhaka, Bangladesh

${ }^{4}$ Associate Professor, Division of Neonatal Cardiology, Department of Paediatric Cardiology, Bangladesh Institute of Child Health (BICH), Dhaka Shishu (Children) Hospital, Dhaka, Bangladesh

${ }^{5}$ Registrar, Department of Paediatric Infectious Diseases and Community Paediatrics, Bangladesh Institute of Child Health (BICH), Dhaka Shishu (Children) Hospital, Dhaka, Bangladesh

${ }^{6}$ Assistant Professor, Department of Paediatric Infectious Diseases and Community Paediatrics, Bangladesh Institute of Child Health (BICH), Dhaka Shishu (Children)Hospital, Dhaka, Bangladesh
}

DOI: $\underline{10.36347 / \text { sjams.2020.v08i08.028 }}$

| Received: 16.08.2020 | Accepted: 23.08.2020 | Published: 30.08.2020

*Corresponding author: Dr. Md. Mizanur Rahman

Abstract Original Research Article

Introduction: Enteric (Typhoid) fever is a bacterial infection which can spread all over the body, affecting several organs. The lack of proper treatment can cause serious complications and can be fatal. It is mainly caused by a bacterium called Salmonella enterica serovar Typhi which is related to the bacteria that cause salmonella food poisoning. It is a major public health issue in developing and developed countries. Aim of the study: To assess the prevalence of Enteric fever which are affecting by socio-demographic factors. Material \& Methods: This was an observational study which was conducted at the Department of Paediatric Infectious Diseases and Community Paediatrics, Bangladesh Institute of Child Health (BICH), Dhaka Shishu (Children) Hospital, Dhaka, Bangladesh. The study was conducted from January 2018 to December 2018. Total 133 cases were selected using random sampling technique. Informed written consent was obtained from each patient before the procedure. A pre-designed questioner had been used to collect all the necessary data from the participants. Program MS-Excel was used in collecting data, SPSS version 21 was used in analyzing data. On the other hand, several tables were used to disseminate data. Following was the inclusion and exclusion criteria of the present study. Results: Of the total 133 study subjects, $60.2 \%$ were aged $<60$ months, and the rest $39.8 \%$ were aged $\geq 60$ months; Mean age (Mean \pm SD) in months were 55.26 \pm 36.20 ; age range were 7-172 months. Male subjects were $71(53.4 \%)$ and female subjects were $62(46.6 \%)$; male to female ratio was 1.1: 1 . Among the total study subjects, $116(87.2 \%)$ were from urban area, $4(3 \%)$ were from urban slum area and the rest $13(9.8 \%)$ were from rural area. Distribution of mother's education reflects that, majority $(41.4 \%)$ of the mothers were educated up to class $10,29(21.8 \%)$ were graduated and only $9 \%$ were post graduated Monthly income of the family reflects that, majority $(43.6 \%)$ of the family's income per month was $>30000$ tk, $38(28.6 \%)$ was between $15000-30000$ tk and the rest $37(27.8 \%)$ were $<15000$ tk. The distribution of the study subjects by drinking water that demonstrates majority (50.4\%) of the patients drink tap water, 21(15.8\%) drink tube well water and others were $45(33.8 \%)$. Distribution of the study subjects by boiling of drinking water shows, majority (78.9\%) were drinking boiled water and $28(21.1 \%)$ were not. Distribution of the study subjects by hand washing is shown which describe that, 24(18\%) had the habit of washing hand before meal, 13(9.8\%) had the habit of washing hand after toilet and 96(72.2\%) had both the habit. Conclusion: In this study, it is observed that, socio-demographic factors such as age, sex, place of living and sources of domestic water play vital role in prevalence of Enteric fever.

Keywords: Enteric fever, Typhoid, Paediatrics, socio-demographic factors.

Copyright @ 2020: This is an open-access article distributed under the terms of the Creative Commons Attribution license which permits unrestricted use, distribution, and reproduction in any medium for non-commercial use (NonCommercial, or CC-BY-NC) provided the original author and source are credited. 


\section{INTRODUCTION}

Enteric (Typhoid) fever is a bacterial infection which can spread all over the body, affecting several organs. The lack of proper treatment can cause serious complications and can be fatal. It is mainly caused by a bacterium called Salmonella enterica serovar Typhi which is related to the bacteria that cause salmonella food poisoning. It is a major public health issue in developing and developed countries. Approximately, 21.6million people suffer from this disease, and it occurs almost 216,500 deaths every year $[1,2]$. Nearly $80 \%$ of the suffering and death cases were reported from Asia, whereas the rest (20\%) of them were from Africa and Latin America [2]. In South Asia, it is assessed that approximately 400 million people ( $23 \%$ of the population) subsists in high-risk situations for aquatic diseases ${ }^{3}$. It is determined that Enteric fever is most seen in parts of the world that have poor sanitation and limited access to clean water. Although, people of various age are being affected, but children are considered to be most at risk of developing typhoid fever. This may be for the reason that their immune system is still developing. But children with typhoid fever tend to have milder symptoms than adults. Some recent evidence from Delhi has specified that the prevalence of affected by typhoid fever is significantly superior in preschool children [4]. Higher morbidities as well as occurrence of multidrug-resistant isolates has made effective therapy of typhoid very challenging as first-line drugs are dropping their effectiveness against the organism [5]. There is also substantial epidemiological interest in the seasonal difference of pediatric typhoid fever. The effect of climatic factors is considerable and prophylactic actions for the summer months are encouraged [6, 7]. Despite the fact that, the major cause of Salmonella enterica serovar Typhi infection is through contaminated food and water, a considerable number of causes add to disease burden in endemic settings [8]. Such factors are poor sanitation, contact with carriers, living near bodies of stagnant water, climatic conditions, and socioeconomic contexts (eg, literacy rates, food and water consumption patterns) $[9,10]$. In short, low socio-economic status and poor hygiene conditions $[1,11]$ are responsible for the spread of the infection $[12,13]$. Therefore, this study aims to observe the socio-demographic factors that affects the prevalence of Enteric fever.

\section{Methodology and Materials}

This was an observational study which was conducted at the Department of Paediatric Infectious Diseases and Community Paediatrics, Bangladesh Institute of Child Health (BICH), Dhaka Shishu (Children) Hospital, Dhaka, Bangladesh. The study was conducted from January 2018 to December 2018. The aim of the study was to assess the prevalence of Enteric fever which are affecting by socio-demographic factors. Total 133 cases were selected using random sampling technique. Informed written consent was obtained from each patient before the procedure. A pre-designed questioner had been used to collect all the necessary data from the participants. Program MS-Excel was used in collecting data, SPSS version 21 was used in analyzing data. On the other hand, several tables were used to disseminate data. Following was the inclusion and exclusion criteria of the present study.

\section{Inclusion Criteria}

- Patients admitted at at the Department of Paediatric Infectious Diseases and Community Paediatrics, Bangladesh Institute of Child Health (BICH), Dhaka Shishu (Children) Hospital, Dhaka, Bangladesh

- Patient aged below 16 years

\section{Exclusion Criteria}

- Patients aged above 16 years

\section{RESULTS}

Of the total 133 study subjects, $60.2 \%$ were aged $<60$ months, and the rest $39.8 \%$ were aged $\geq 60$ months; Mean age (Mean \pm SD) in months were $55.26 \pm 36.20$; age range were 7-172 months. Male subjects were $71(53.4 \%)$ and female subjects were 62 $(46.6 \%)$; male to female ratio was 1.1: 1 . Of the total study subjects, $116(87.2 \%)$ were from urban area, 4 $(3 \%)$ were from urban slum area and the rest $13(9.8 \%)$ were from rural area. Distribution of mother's education reflects that, majority $(41.4 \%)$ of the mothers were educated up to class $10,29(21.8 \%)$ were graduated and only $9 \%$ were post graduated. Monthly income of the family shown in the last part of Table-1 reflects that, majority $(43.6 \%)$ of the family's income per month was $>30000$ tk, 38(28.6\%) was between 15000-30000tk and the rest $37(27.8 \%)$ were $<15000$ tk. Table-2 shows the distribution of the study subjects by drinking water that demonstrates majority $(50.4 \%)$ of the patients drink tap water, 21(15.8\%) drink tube well water and others were $45(33.8 \%)$. Distribution of the study subjects by boiling of drinking water (Table-3) shows, majority (78.9\%) were drinking boiled water and $28(21.1 \%)$ were not. In Table-4 distribution of the study subjects by hand washing is shown which describe that, $24(18 \%)$ had the habit of washing hand before meal, $13(9.8 \%)$ had the habit of washing hand after toilet and 96(72.2\%) had both the habit. Distribution of the study subjects by hand washing after defecation with, and distribution of the study subjects by H/O typhoid vaccination is shown in Table 5 and 6 respectively. 
Table-1: Demographic characteristics of the study subjects $(n=133)$ \begin{tabular}{|l|l|l|}
\hline Demographic characteristics & Frequency & Percentage (\%) \\
\hline
\end{tabular}

Age (in months)

\begin{tabular}{|l|l|l|}
\hline$<60$ & 80 & 60.2 \\
\hline$\geq 60$ & 53 & 39.8 \\
\hline Total & 133 & 100.0 \\
\hline Mean \pm SD & $55.26 \pm 36.20$ \\
\hline Range & $(7-172)$ months \\
\hline Sex & \multicolumn{2}{|l|}{}
\end{tabular}

\begin{tabular}{|l|l|l|}
\hline Male & 71 & 53.4 \\
\hline Female & 62 & 46.6 \\
\hline Male : Female ratio & $1.1: 1$ & \\
\hline Residence &
\end{tabular}

Residence

\begin{tabular}{|l|l|l|}
\hline Urban & 116 & 87.2 \\
\hline Urban slum & 4 & 3.0 \\
\hline Rural & 13 & 9.8
\end{tabular}

\begin{tabular}{|l|l|l|}
\hline Mother's education & \multicolumn{2}{l|}{} \\
\hline Class 1-10 & 55 & 41.4 \\
\hline SSC & 15 & 11.3 \\
\hline HSC & 22 & 16.5 \\
\hline Graduate & 29 & 21.8 \\
\hline Post graduate & 12 & 9.0 \\
\hline \multicolumn{2}{|l|}{} \\
\hline Motal & 133 & 100.0 \\
\hline$<15000$ & 37 & 27.8 \\
\hline $15000-30000$ & 38 & 28.6 \\
\hline$>30000$ & 58 & 43.6 \\
\hline Total & 133 & 100.0 \\
\hline
\end{tabular}

Table-2: Distribution of the study subjects by drinking water $(n=133)$

\begin{tabular}{|l|l|l|}
\hline Drinking water & Frequency & Percentage (\%) \\
\hline Tap water & 67 & 50.4 \\
\hline Tube well & 21 & 15.8 \\
\hline Others & 45 & 33.8 \\
\hline Total & 133 & 100.0 \\
\hline
\end{tabular}

Table-3: Distribution of the study subjects by boiling of drinking water $(n=133)$

\begin{tabular}{|l|l|l|}
\hline Boiling of drinking water & Frequency & Percentage (\%) \\
\hline Yes & 105 & 78.9 \\
\hline No & 28 & 21.1 \\
\hline Total & 133 & 100.0 \\
\hline
\end{tabular}

Table-4: Distribution of the study subjects by hand washing $(n=133)$

\begin{tabular}{|l|l|l|}
\hline Hand washing & Frequency & Percentage (\%) \\
\hline Before meal & 24 & 18.0 \\
\hline After toilet & 13 & 9.8 \\
\hline Both & 96 & 72.2 \\
\hline Total & 133 & 100.0 \\
\hline
\end{tabular}

Table-5: Distribution of the study subjects by hand washing after defecation with $(\mathrm{n}=133)$

\begin{tabular}{|l|l|l|}
\hline Hand washing after defecation & Frequency & Percentage (\%) \\
\hline Soap & 124 & 93.2 \\
\hline Ash & 4 & 3.0 \\
\hline Only water & 5 & 3.8 \\
\hline Total & 133 & 100.0 \\
\hline
\end{tabular}


Table-6: Distribution of the study subjects by $H / O$ typhoid vaccination $(n=133)$

\begin{tabular}{|l|l|l|}
\hline H/O of vaccination & Frequency & Percentage (\%) \\
\hline Yes & 15 & 11.3 \\
\hline No & 118 & 88.7 \\
\hline Total & 133 & 100.0 \\
\hline
\end{tabular}

\section{Discussion}

In the present study, of the total 133 study subjects, $60.2 \%$ were aged $<60$ months, and the rest $39.8 \%$ were aged $\geq 60$ months. Chandrasekhar et al., [14] in their study showed that $60 \%$ of typhoid patients were above 5 years of age which is almost similar to our study. Another study from a Tertiary care hospital in Chennai, South India showed that $169(53.48 \%)$ out of 316 cases of typhoid fever were $>5$ years of age [15]. Also, there were a total of the 14 studies that included to analyze the children under-5 age group, where 3 studies [16-18] estimated that $<15 \%$ of disease was in this age group, whereas 3 studies [19-21] estimated that more than half the disease occurrence was in this age group. In our study male subjects were $71(53.4 \%)$ and female subjects were $62(46.6 \%)$; male to female ratio was 1.1: 1. Two different studies by Oboegbulam et al., [22] and Agbakwuru et al., [23] showed that typhoid fever is more prevalent in males than females. Meanwhile, Zailani et al., [24] found no influence of age, sex and social class on the distribution pattern of Salmonella enterica serovar Typhi and Salmonella enterica serovar Paratyphi in Ile-Ife, south western Nigeria. Majority $(50.4 \%)$ of our study participants drink tap water, 21(15.8\%) drink tube well water and others were $45(33.8 \%)$. Distribution of the study subjects by boiling of drinking water alson showed, majority $(78.9 \%)$ were drinking boiled water and $28(21.1 \%)$ were not. Even though, a straight link between well water and typhoid fever infection may be challenging to inaugurate, probable contamination of most well water might be a most important influential aspect to the high infection frequency [25]. A survey showed that most of the wells are dug close to the soak away and septic tanks and this must have exhilarated the seepage of human waste which is a verified means of spread of the infection agent into the water source [26]. Even though studies reported that there is no noteworthy difference on the incidence of typhoid between urban and rural environments [27], in this study urban residents were associated with higher risk of typhoid fever as compared to rural residents. This could be explained by suboptimal access to safe water and lack of hygienic environment in the rural areas of Bangladesh. In addition, this study was conducted in a tertiary care hospital which is situated in the urban area. So this might be another reason behind observing the superior proportion of people getting affected by Enteric fever in urban area than rural area.

\section{LIMITATIONS OF THE STUDY}

This was an observational study conducted in a single centered unit. The sample size was comparatively small. So, it might not reflect the scenario of the whole country.

\section{CONCLUSiON AND \\ RECOMMENDATIONS}

In this study, it is observed that, sociodemographic factors such as age, sex, place of living and sources of domestic water play vital role in prevalence of Enteric fever. It is concluded that, campaigns by the Government and policy makers on the importance of hygiene should be take place among the urban and rural area to educate general people. Furthermore, public health agencies should base plans to control the disease. Moreover, awareness should be spread through media such as television and newspapers.

\section{REFERENCES}

1. Akent L, Hassen M, Ahmed Z. Present status and antibiotic sensitivity pattern of Salmonellae typhi and Salmonellae paratyphi in different age group hospitalized patients in Dhaka city, Bangladesh. J Pharm Biol Sci. 2012; 4:27-30.

2. Crump JA, Luby SP and Mintz ED. The global burden of typhoid fever. Bull World Health Organ. 2004; 82:346-353.

3. Mogasale V, Maskery B, Ochiai RL, Lee JS, Mogasale VV, Ramani E, Kim YE, Park JK, Wierzba TF. Burden of typhoid fever in lowincome and middle-income countries: a systematic, literature-based update with risk-factor adjustment. The Lancet Global health. 2014 Oct 1;2(10):e57080 .

4. Sinha A, Sazawal S, Kumar R, Sood S, Reddaiah VP, Singh B, Rao M, Naficy A, Clemens JD, Bhan MK. Typhoid fever in children aged less than 5 years. The Lancet. 1999 Aug 28;354(9180):734-7.

5. Saqib A, Ahmed A. Culture and sensitivity of Salmonella species; analysis of a two year data. J Pak Med Assoc. 2000; 50:282-4.

6. Geernaat HBPE, Dechering WHJC, Voorhoeve HWA. Clinical epidemiology of pediatric disease at Nchelenge, North-East Zambia. Ann Trop Paed. 1998; 18:129-38.

7. Rio M, Garcia JM, Cubedo M, Prez D. Time series in the epidemiology of typhoid fever in Spain. Med Clin Barc. 1996; 106:686-9.

8. Siddiqui TR, Bibi S, Mustufa MA, Avaz SM, Khan A. High prevalence of typhoidal Salmonella enterica serovars excreating food handlers in Karachi-Pakistan: a probable factor for regional 
typhoid endemicity. J Health Popul Nutr. 2015; 33:27.

9. Dewan AM, Corner R, Hashizume M, Ongee ET. Typhoid fever and its association with environmental factors in the Dhaka metropolitan area of Bangladesh: a spatial and time-series approach. PLoS Negl Trop Dis. 2013; 7:e1998.

10. Corner RJ, Dewan AM, Hashizume M. Modelling typhoid risk in Dhaka Metropolitan Area of Bangladesh: the role of socio-economic and environmental factors. Int J Health Geogr. 2013; 12:13.

11. Mweu E and English M. Typhoid fever in children in Africa. Trop Med Int Health. 2008; 13(4): 532540.

12. Senthilkumar B, Senbagam D, Rajasekarapandian M. An epidemiological surveillance of asymptomatic typhoid carriers associated in respect to socioeconomic status in India. J Public Health. 2012; 22: 297-301.

13. Sivaji I, Duraisamy S, Balakrishnan S, Periasamy S. A prevalence study of typhoid fever and convalescent phase asymptomatic typhoid carriers among the schoolchildren in the northern part of Tamil Nadu. Journal of Public Health. 2015 Dec 1;23(6):373-8.

14. Chandrashekar, Anil Kumar YC, Kirandeep Sodhi, Dalal SS (2013) Study of clinical and laboratory profile of Enteric fever in pediatric age group. Int J Basic Appl Med Sci 3: 16-23.

15. Ganesh R, Janakiraman L, Vasanthi T, Sathiyasekeran M. Profile of typhoid fever in children from a tertiary care hospital in ChennaiSouth India. The Indian Journal of Pediatrics. 2010 Oct 1;77(10):1089-92.

16. Karkey A, Arjyal A, Anders KL, Boni MF, Dongol S, Koirala S, My PV, Nga TV, Clements AC, Holt KE, Duy PT. The burden and characteristics of enteric fever at a healthcare facility in a densely populated area of Kathmandu. PloS one. 2010 Nov 15;5(11):e13988.

17. Kelly DF, Thorson S, Maskey M, Mahat S, Shrestha U, Hamaluba M, Williams E, Dongol S, Werno AM, Portess H, Yadav BK. The burden of vaccine-preventable invasive bacterial infections and pneumonia in children admitted to hospital in urban Nepal. International journal of infectious diseases. 2011 Jan 1;15(1):e17-23.

18. Kumar S, Rizvi M, Berry N. Rising prevalence of enteric fever due to multidrug-resistant Salmonella: an epidemiological study. J Med Microbiol. 2008; 57:1247-50.

19. Malla T, Malla KK, Thapalial A, Shaw C. Enteric fever: a retrospective 6-year analysis of 82 paediatric cases in a teaching hospital. Kathmandu Univ Med J (KUMJ). 2007; 5:181-7.

20. Ochiai RL, Acosta CJ, Danovaro-Holliday M, Baiqing D, Bhattacharya SK, Agtini MD, Bhutta ZA, Canh DG, Ali M, Shin S, Wain J. A study of typhoid fever in five Asian countries: disease burden and implications for controls. Bulletin of the world health organization. 2008;86:260-8.

21. Parry CM, Thompson C, Vinh H, Chinh NT, Ho VA, Hien TT, Wain J, Farrar JJ, Baker S. Risk factors for the development of severe typhoid fever in Vietnam. BMC infectious diseases. 2014 Dec $1 ; 14(1): 73$.

22. Oboegbulam SI, Guganani HC. Microbiological studies on cases diagnosed as typhoid fever in South-east Nigeria. J. Comm. Dis. 1995;27(2):97100

23. Agbakwuru EA, Adesunkanmi AR, Fadiora SO, Olayinka OS, Aderonmu AO, Ogundoyin OO. A review of typhoid perforation in rural African Hospital. West African Medicine. 2003;22(1):2225.

24. Zailani SB, Aboderin AO, Onipede AO. Effect of socio-economic status, age and sex on antibody titre profile to Salmonella typhi/paratyphi in Ile-Ife, Nigeria. Niger J Med. 2004; 13(4):383-7.

25. Okome M. Bekale J, Kombila M. Typhoid and paratyphoid fever in adults in the Internal Medicine Department at Libreville (Gabon) Sante. 2000;10(3):205-209

26. Kan KM. Serotype epidemiology and patterns of antibiotic susceptibility of Salmonella isolated in Hong Kong. China Medical Journal. 1996;109(4):276-281.

27. Dewan AM, Corner R, Hashizume M, Onge ET. Typhoid fever and its association with environmental factors in the Dhaka Metropolitan Area of Bangladesh: a spatial and time-series approach. PLoS Negl Trop Dis. 2013;7(1):e1998. 